\title{
Improving the efficiency of assessing the quality of training of future engineers-teachers using the author's mathematical model
}

\author{
Yefremova 0.* \\ Institute of Pedagogical and Adult Education NAPS of Ukraine, Kyiv, Ukraine
}

Received: $09.07 .2020 \quad$ Accepted: 30.07 .2020

\begin{abstract}
The development and implementation of models for determining the quality of professional training of future specialists remain significant problems for pedagogical science and practice. The relevance of the study confirms the fact that the change in requirements for training requires finding new approaches to quality management of the educational process of the university and all-round quality of the study. This raises the question of what performance is characterized by the quality of training, and how they can be measured in the educational process. To effectively solve the problem of quality of educational process management has been developed and multifactor mathematical model of quality tested experimentally. Using this model, it is possible to scientifically determine the parameters that influence the quality as much as possible, rank the parameters by the "strength of their influence" on the quality and predict the dependence of the quality change on the change in its parameters by $1 \%$. Interpretation of parameters has been solved with the help of «Diagnostic Center» author's computing environment, diagnostic tests and the grading scale. The developed mathematical model can be built for any educational institution, for various specialties, the influence of external and internal factors. The accuracy of the model building will be the higher, the greater the statistical data used in the conclusion of multivariate equations. To confirm the effectiveness of our proposed innovative methodology for diagnosing the levels of quality parameters, a pedagogical experiment was conducted. The results obtained in the process of the pedagogical experiment give grounds to assert that the developed methodology for comprehensive quality diagnosis using the author's computer environment "Diagnostic Center" gave a positive result and helped to increase the quality levels of training of future specialists.
\end{abstract}

Key words: quality of training of engineer-teachers, mathematical model, multiple regression, pedagogical experiment, computer environment for diagnostics.

\section{Підвищення ефективності оцінювання якості підготовки майбутніх інженерів-педагогів за допомогою авторської математичної моделі}

Єфремова О.В.

\author{
Інститут педагогічної освіти і освіти дорослих НАПН України, Київ, Україна
}

\begin{abstract}
Анотація. Розробка та впровадження моделей оцінки якості професійної підготовки майбутніх фахівців залишаються значущими проблемами для педагогічної науки i практики. Актуальність дослідження підтверджує той факт, що зміна вимог до підготовки фахівців потребує знаходження нових підходів до управління якістю навчального процесу вишу та всебічного дослідження якості. Тому виникає питання про те, якими показниками характеризується якість професійної підготовки, і яким чином вони можуть бути виміряні у навчально-виховному процесі. Для ефективного розв'язання проблеми управління якістю навчальновиховного процесу була розроблена та експериментально перевірена багатофакторна математична модель якості підготовки майбутнього фахівця, за допомогою якої можна науково визначити параметри, що максимально впливають на якість, ранжувати параметри по "силі їх впливу" на якість та прогнозувати залежність зміни якості від зміни їі параметрів на 1\%. Інтерпретація параметрів була вирішена за допомогою авторського комп'ютерного середовища «Diagnostic Center», діагностичних тестів, які розроблені за його допомогою та бальної шкали. Розроблена математична модель може бути побудована для будь-якого навчального закладу, різних напрямів підготовки майбутніх фахівців, впливу зовнішніх і внутрішніх чинників. При цьому точність побудови моделі буде тим вище, чим більше статистичних даних використовувалося при виводі багатофракторних рівнянь. Для підтвердження ефективності запропонованої нами інноваційної
\end{abstract}

Corresponding Author: Yefremova Oksana Volodymyrivna. Tel. +38(050)982-38-27. E-mail: efremovaoksana7@gmail.com Institute of Pedagogical and Adult Education NAPS of Ukraine, st. M. Berlinsky, 9, Kyiv, Ukraine, 04060.

Відповідальний автор: Єфремова Оксана Володимирівна. Tel. +38(050)982-38-27. E-mail: efremovaoksana7@gmail.com Інститут педагогічної освіти і освіти дорослих НАПН України, вул. М. Берлинського, 9, м. Київ, Україна, 04060. 
методики комплексного діагностування рівнів параметрів якості проведено педагогічний експеримент, що складався з констатуючого, формуючого та контрольного етапів. Аналіз результатів, отриманих в процесі педагогічного експерименту, дає підстави стверджувати, що розроблена методика комплексного діагностування якості за допомогою авторського комп'ютерного середовище «Diagnostic Center» дала позитивний результат і сприяла підвищенню рівнів якості підготовки майбутніх фахівців.

Ключові слова: якість підготовки інженерів-педагогів, математична модель, множинна регресія, педагогічний експеримент, комп'ютерне середовище для діагностування.

\title{
Повышение эффективности оценивания качества подготовки будущих инженеров-педагогов с помощью авторской математической модели
}

\author{
Ефремова О. В.
}

\author{
Институт педагогического образования и образования взрослых НАПН Украины, Киев, Украина
}

\begin{abstract}
Аннотация. Разработка и внедрение моделей оценки качества профессиональной подготовки будущих специалистов остаются значимыми проблемами для педагогической науки и практики. Актуальность исследования подтверждает тот факт, что изменение требований к подготовке специалистов требует нахождения новых подходов к управлению качеством учебного процесса вуза и всестороннего исследования качества. Поэтому возникает вопрос о том, какими показателями характеризуется качество профессиональной подготовки, и каким образом они могут быть измерены в учебно-воспитательном процессе. Для эффективного решения проблемы управления качеством учебно-воспитательного процесса была разработана и экспериментально проверена многофакторная математическая модель качества подготовки будущего специалиста, с помощью которой можно научно определить параметры, максимально влияющих на качество, ранжировать параметры по "силе их влияния" на качество и прогнозировать зависимость изменения качества от изменения ее параметров на 1\%. Интерпретация параметров была решена с помощью авторской компьютерной среды «Diagnostic Center», диагностических тестов, которые разработаны с ее помощью и бальной шкалы. Разработанная математическая модель может быть построена для любого учебного заведения, различных направлений подготовки будущих специалистов, влияния внешних и внутренних факторов. При этом точность построения модели будет тем выше, чем больше статистических данных использовалось при выводе многофакторных уравнений. Для подтверждения эффективности предложенной нами инновационной методики комплексного диагностирования уровней параметров качества проведен педагогический эксперимент, состоящий из констатирующего, формирующего и контрольного этапов. Анализ результатов, полученных в процессе педагогического эксперимента, дает основания утверждать, что разработанная методика комплексного диагностирования качества с помощью авторской компьютерной среды «Diagnostic Center» дала положительный результат и способствовала повышению уровней качества подготовки будущих специалистов.

Ключевые слова: качество подготовки инженеров-педагогов, математическая модель, множественная регрессия, педагогический эксперимент, компьютерная среда для диагностирования.
\end{abstract}

\section{Bcmyn}

Вступ України до Болонського процесу висуває нові вимоги до рівня підготовки майбутніх інженерів-педагогів, необхідність розробки моделі підготовки фахівця, в якій висвітлюються якісні результати освітнього процесу $[1,21]$. Але не зважаючи на актуальність цього питання, слід визнати, що в інженерно-педагогічній освіті сьогодні накопичилося багато проблем і ряд негативних тенденцій, серед яких можна виділити різке зниження рівня професійної підготовки сучасної молоді, їх пізнавальної активності і самостійності. Це негативно відбивається на якості знань і умінь студентів вузу, їх інтелектуальному розвиткові, а також рівні їх фахової підготовки.

Аналіз загального стану теорії і практики оцінки якості та підвищення конкурентоспроможності підготовки майбутніх інженерів-педагогів дозволив виявити ряд недоліків і невирішених проблем:

- відсутність чіткої стратегії розвитку якості інженерно-педагогічної освіти;

- оцінка якості результатів навчання у вузі не в повній мірі враховує особистісні та професійні якості майбутнього фахівця;

- недостатньо теоретично опрацьована сутність понять рівень якості підготовки, конкурентоспроможність, не розроблені чіткі критерії і параметри що впливають на якість;

- не пропонуються наукові методи коригування показників якості підготовки фахівця; 
- відсутність єдиних ефективних діагностичних інструментаріїв і технологій комплексного діагностування та прогнозування якості;

- існуючі підходи до побудови моделі підготовки фрахівця в основному даються на описовому (теоретичному) рівні і не завжди враховують практично-прикладний характер.

Тому виникає питання розробки ефективної та інноваційної методики комплексного діагностування рівнів параметрів якості 3 використанням авторського комп'ютерного середовища «Diagnostic Center» в основі якого лежить побудова математичної моделі.

Практично всі дослідники проблем управління та оцінки якості підготовки фахівців $[9,10,13,17$, 22, 24] вважають, що для подолання негативних явищ у цій сфрері в умовах інформаційного суспільства необхідно активно і цілеспрямовано використовувати інноваційні засоби і методи педагогічної діагностики, які повинні стати основою побудови моделей майбутнього фахівця.

Розробка моделей фахівця має значне теоретико-методологічне підірунтя, оскільки у вітчизняній та зарубіжній педагогіці накопичено достатній досвід розробки різних моделей, використовуваних 3 метою побудови уявлення про сутність профресійної діяльності фрахівця, а також проектування процесу його підготовки.

Питанням створення моделей якості навчальних досягнень студентів та результативності навчального процесу присвятили свої наукові розвідки Н. Байдацька [2], Л. Коробович [11], О. Сергєєва [20], О. Туржанська [23], С. Завістовскій [6], Т. Олендр [15, 16], І. Потай [18], В. Рогожин [19], а також M. Brookes [27], N. Downie [27], A. Irving [30], A. Powell [30], A. Hunt [30], М. Tam [32]. У студіях Г. Шабанова [24], P. Ramsden [31] розроблено моделі педагогічного забезпечення якості навчального процесу.

Під моделлю сучасного фахівця розуміють науково обґрунтований, детально описаний еталон особистості майбутнього фахівця, отриманий у результаті підготовки у ВН3, у якому поєднуються його особистісні та професійні якості [19]. Вона $є$ необхідною складовою освітнього процесу вузу включає уявлення про мету діяльності фахівця, функціональні обов'язки, професійно значущі якості, нормативних умовах організації майбутньої професійної діяльності і використовується в якості основи для побудови індивідуальної освітньої траєкторії навчання майбутнього фрахівця.

Усі дослідники при розв'язанні проблеми розробки моделей фахівця виходили з того, що вищий навчальний заклад повинен мати деякий зразок, у якому відображено вимоги практики й перспективи підготовки фахівців. Було визначено, що модель фахівця повинна мати вигляд розгорнутого документа, який відображає вимоги до знань випускників, їхніх навичок, умінь, психологічних і моральних якостей, що забезпечить наступну ефективну діяльності в усіх сфрерах народного господарства країни. В основу розробки власної моделі було покладено модель процесу підготовки фрахівця, що є основою для забезпечення якості.

В даний час у сфрері освіти застосовуються такі моделі управління якістю [28]:

- модель, що відповідає вимогам концепції ТQМ;

- модель системи менеджменту якості за міжнародним стандартом ISO 9001:2015 [12];

- модель Європейського фонду по менеджменту якості (EFQM) і її модифікація для вищої освіти;

- модель Центру досліджень і політики в галузі вищої освіти (CHEPS) університету Твенте (Нідерланди);

- модель Асоціації університетів Нідерландів (VSNU) [33];

- Бельгійсько-нідерландська модель (HBO Expert Group);

- модель національної американської премії за якістю «Baldrige National Quality Award» в галузі освіти, 2005 рік.

Певне значення щодо нашого дослідження має структура моделі моніторингу, визначена Т. Олеандр на основі вивчення досвіду моніторингу якості університетської освіти США [15]. Дослідницею акцентовано увагу на існуванні етапів проведення моніторингу, його сутності при визначенні якості процесного та результативного складників освітнього процесу, інструментарію моніторингу, а також таких його невід'ємних складників, як об'єкт, суб'єкти та критерії.

Як свідчать результати ґрунтовного дослідження N. Becket та M. Brookes проблем оцінки якості у вищій освіті, використання методів та інструментів моніторингових досліджень у вищих навчальних закладах відповідно до цих моделей потребує значного коригування та адаптування [26]. Говорячи про 
основні вимоги до організації моніторингу у вищому навчальному закладі, дослідниці вказують на необхідність: комплексного дослідження процесів та результатів професійної підготовки; залучення всіх учасників навчального процесу як суб'єктів моніторингу; чіткого визначення критеріїв оцінки якості; виявлення взаємозв'язку між якістю та складниками освітнього процесу з метою спрямування та глибини моніторингових досліджень.

Аналіз досвіду зарубіжних науковців свідчить, що взагалі управління якістю підготовки фрахівців у вищих навчальних закладах багатьох країн світу ґрунтується на принципах Загального управління якістю (TQM) та вимогах міжнародних стандартів якості ISO 9001:2015 [21]. Це передбачає наявність діагностування як обов'язкового елемента систем управління якістю.

Передбачалось, що основоположною ідеєю при моделюванні була розробка такої моделі, яка дозволила б підвищити есрективність процесу підготовки майбутніх інженерів-педагогів, привести його у відповідність з висунутими вимогами сучасного суспільства. 3 огляду на це, автором розроблена багатофакторна математична модель якості підготовки майбутнього фахівця, в основі якої лежить метод кореляційно-регресійного аналізу [5].

Метою статті є підвищення ефективності оцінювання якості підготовки майбутніх інженерівпедагогів за допомогою авторської математичної моделі.

Також в роботі визначено завдання дослідно-експериментальної роботи, а саме: визначення вхідного і підсумкового рівнів якості професійної підготовки студентів; оцінка параметрів моделі на підставі статистичних даних; перевірка отриманої моделі на адекватність; реалізація та впровадження авторських математичної моделі та комп'ютерного середовища «Diagnostic Center» в навчальний процес ВН3; вибір експериментальних і контрольних груп; опрацювання експериментальних даних за допомогою математико-статистичних методів і авторської моделі з метою підвищення обґрунтованості висновків.

\section{II Матеріал і методи дослідження}

У ході дослідження проведений аналіз вітчизняних і зарубіжних публікацій, що відносяться до теми дослідження, спеціальної методичної літератури, присвяченої питанням ефективності застосування різних моделей якості підготовки майбутнього фахівця, використання інноваційних методів педагогічної діагностики у вищій школі, використанню спеціальних інструментальних комп'ютерних програм, що дозволяють створювати діагностичні тести.

Експериментальною базою дослідження виступили наступні вузи: Стахановський навчальнонауковий інститут гірничих та освітніх технологій Української інженерно-педагогічної академії, Українська інженерно-педагогічна академія, Східноукраїнський національний університет ім. В. Даля. Експериментальна робота проводилася протягом п'яти років (2013-2018 р.р.) в три етапи: I етап констатуючий; II - формуючий; III - контрольний експеримент.

Під час констатувального експерименту нами використовувалися такі методи дослідження як: комп'ютерне діагностичне тестування та анкетування; спостереження за навчальною діяльністю студентів; бесіди зі студентами і викладачами; вивчення й узагальнення педагогічного досвіду; методи математичної статистики, комп'ютерна обробки даних, шкалування. На цьому етапі нашого дослідження ми спробували висунути гіпотезу та розкрити найбільш істотні параметри, які впливають на якість підготовки майбутніх фахівців на сучасному етапі. Також був ретельно підібраний і розроблений набір психолого-педагогічних методик для проведення діагностування цих показників якості. Для визначення рівня сфрормованості кожного показника якості та результатів професійної підготовки студента в цілому ми позначили їх через низький, середній, достатній і високий. При діагностичному тестуванні домовилися враховувати тільки високий рівень підготовки майбутнього інженера-педагога.

Формувальний експеримент проводився впродовж 4-ох навчальних років для практичної перевірки моделі на адекватність. Вибірку складали дві групи студентів першого курсу контрольних (КГ) та експериментальних груп (ЕГ), які були залучені в констатувальному експерименті і навчалися у ВН3 з 1-го по 4-й курси відповідно. В обох категоріях груп була майже однакова кількість студентів: в КГ - 32 студенті а в ЕГ - 36 майбутніх інженерів-педагогів. У дослідженні ми виходили з того, що перевірку гіпотези можна здійснити, якщо вивчати динаміку і рівні якості професійної підготовки майбутніх фахівців на різних етапах дослідження. Для цього нами проводилися контрольні зрізи на початку 
формувального експерименту, безпосередньо в процесі його проведення і після його завершення в контрольних і експериментальних групах. Об'єктивність в процесі аналізу результатів дослідження досягалася тим, що експериментальними групами ми обирали ті групи, які в констатувальному експерименті мали нижчі показники, ніж контрольні групи. Потрібно зазначити важливість цього моменту, оскільки відносна однорідність студентів у групах за кількісними та якісними показниками забезпечує більшу достовірність результатів дослідження.

Отож зазначимо, що одним із найголовніших чинників на початковому етапі формувального експерименту було забезпечення однакових стартових умов для студентів $Е Г$ і КГ. Аналіз і обробка результатів експерименту здійснювалися за єдиною програмою, в ідентичних умовах, з використанням єдиної методики діагностичних вимірювань якості підготовки студентів в експериментальній групі. Усе це сприяло одержанню вірогідних експериментальних даних. 3 метою одержання достовірних результатів експерименту, який полягав в дослідженні параметрів та їх корекції, вихідними стали визначення рівнів якості цих параметрів і якість професійної підготовки майбутніх фахівців.

Контрольний експеримент проводився з метою контролю і узагальнення результатів наукового пошуку. Вибірку складали ті самі студенти, які були залучені в констатувальному та формувальному експериментах. Під час контрольного експерименту нами були вирішені наступні завдання: визначено рівень профресійної підготовки інженерів-педагогів згідно з корекцією параметрів математичної моделі після формувального експерименту; виконано порівняння якості підготовки груп студентів 3 використанням розробленої технології діагностичних вимірювань та контрольної групи; оброблені, узагальнені і проаналізовані результати педагогічного експерименту, сформульовані висновки. На цьому етапі ми застосовували такі методи, як: аналіз, узагальнення, систематизація матеріалу, статистичні методи вторинної обробки результатів експерименту (методи доказу гіпотези), методи комп'ютерної обробки та методи наочного представлення результатів експерименту. Надійність, валідність, об'єктивність, точність дослідницького інструментарію забезпечували: його адекватність проблемі дослідження; різноманітність форм і методів контролю, в тому числі й комп'ютерна діагностика; три паралельних вибірки експериментальних і контрольних груп; тривалість дослідження; велика кількість проведених вимірювань, їх повторюваність тощо. Щоб визначити достовірність істотної відмінності в одержаних показниках, нами використовувався метод перевірки нульової гіпотези.

\section{III Результати}

Процес комплексного діагностування якості і його аналіз проводився за допомогою авторського комп'ютерного середовища «Diagnostic Center», що дало можливість шляхом багатофакторного і багатовимірного аналізу статистичних результатів навчальних досягнень студентів дослідити якість їх професійної підготовки, визначити його показники і проаналізувати взаємозв'язок показників досліджуваного феномена, а також спрогнозувати залежність зміни якості підготовки студентів від зміни його параметрів. При чому, логіка оцінки якості та його параметрів задається на основі використання математичної моделі і використання методів статистичної обробки результатів.

Для дослідження впливу комплексу різних параметрів на якість підготовки майбутнього фрахівця нами проведено множинний регресійний аналіз. Підкреслимо, що множинна регресія застосовується в ситуаціях, коли з безлічі параметрів, що впливають на якість підготовки майбутнього фахівця, не можна виділити один домінуючий параметр і необхідно враховувати вплив декількох параметрів.

Основна мета множинної регресії - побудувати модель з декількома параметрами і визначити при цьому вплив кожного параметра окремо, а також їх спільний вплив на досліджуваний показник [14].

Тому при побудові багатофакторної моделі необхідно було вирішити питання які параметри якості доцільно включить в модель. Відбір параметрів моделі здійснювалось нами в два етапи: I етап теоретичний аналіз взаємозв'язку результату і кола параметрів, які здійснюють на нього істотний вплив; II етап - кількісна оцінка взаємозв'язку параметрів з результатом.

Аналіз параметрів, які впливають на якість підготовки майбутніх фахівців, дозволяє зробити висновок про те, що цей процес представляє складну динамічну систему і є одним з елементів системи управління якістю ВН3. 
Для найбільш повного опису залежності між якістю підготовки і параметрами, був обраний лінійний вид рівняння регресії. При лінійній формі зв'язку між ознаками даний етап зводиться до аналізу кореляційної матриці (матриці парних лінійних коефріцієнтів кореляції).

Ми спробували висунути гіпотезу та розкрити найбільш істотні параметри, які впливають на якість підготовки майбутніх фахівців на сучасному етапі, тому нами було проаналізовано праці вітчизняних та зарубіжних авторів, посібників і публікацій з проблеми діагностування компетенції студентів В. Аванесова, І. Булах, О. Безносюка, М. Неклюдова, Л. Романішиної, В. Шпильового, Р. Ебеля, Б. Блума, Ф. Галтона, Дж. Кеттелла, У. Холтцмана, П. Лазарсфельда, Л. Гуттмана та ін.; проаналізовано і узагальнено наукові ідеї щодо побудови моделей і методів оцінки якості підготовки фрахівців І. Потай, А. Суслова, П. Канівець, Є. Мелешко та ін.; систематизовано і узагальнено наукові ідеї щодо виявлення стану проблеми забезпечення ефективності процесу навчання та якості його результатів В. Безпалько, В. Лозова, Н. Ничкало, Л. Одерій, В. Онищук, Л. Романишина, Н. Тализіна та ін.; вивчено і узагальнено передовий досвід вузів і окремих викладачів; проаналізовано кваліфікаційні вимоги (галузевий рівень) підготовки студентів спеціальності 015 Професійна освіта (Комп'ютерні технології); проаналізовано законодавчо-нормативну базу України в освітній галузі, яка спрямована на підвищення ефективності роботи навчальних закладів та досягнення якості кінцевого «продукту» (Закони «Про освіту», «Про вищу освіту» та Національну Доктрину розвитку освіти в Україні в XXI столітті).

3 огляду на це, в якості нульової гіпотези до математичної моделі ми включили наступні параметри: $x_{1}$ - якість довузівської підготовки студента; $x_{2}$ - якість викладання в вузі; $x_{3}$ - тести академічних досягнень; $x_{4}$ - педагогічне спілкування; $x_{5}$ - професійна спрямованість (схильність до певних типів професій); $x_{6}$ - інтелект, креативність; $x_{7}$ - культурно-освітній простір вузу; $x_{8}$ - мотивація (ставлення до навчального курсу, дисципліни, професії); $x_{9}$ - духовно-моральна сфрера особистості; $x_{10}$ - усвідомленість вибору професії; $x_{11}$ - толерантність, емпатія.

Зауважимо, що кількість та найменування показників в різних освітніх установах може бути різною, і багато в чому залежить від умови роботи ВНЗ (науково-матеріальної бази вишу, професорсько-викладацького складу, довузівської підготовки абітурієнтів, шкал оцінювання, методів збору статистичного матеріалу і тощо). Запропонована нами система параметрів $€$ авторською та пропонується в якості відправної точки по створенню наукового підходу внутрівузівської системи управління якістю [4].

Також був ретельно підібраний і розроблений набір психолого-педагогічних методик для проведення діагностування цих показників якості. Для визначення рівня сформованості кожного показника якості та результатів професійної підготовки студента в цілому ми позначили їх через низький, середній, достатній і високий. При діагностичному тестуванні домовилися враховувати тільки високий рівень підготовки майбутнього інженера-педагога.

На початковому етапі констатуючого експерименту, процес діагностування проводився для 11 вищеназваних параметрів (число змінних в моделі) в 36 групах (число спостережень). Після побудови моделі з'ясувалося, що на якість підготовки студентів основний вплив має наступні вісім параметрів, які згідно зі статистичними даними складають 79\%, а на частку інших параметрів, про які ми можемо не підозрювати, доводиться 21\%.

На підставі отриманих експериментальних даних ми склали рівняння регресії в «стандартизованому» масштабі див. формулу (1), спосіб отримання коефріцієнтів розшифровано далі по тексту на рис. 1,3 , табл. 1.

$$
t_{y}=0,407 t_{x_{1}}+0,237 t_{x_{2}}+0,17 t_{x_{3}}-0,619 t_{x_{4}}+0,123 t_{x_{5}}+0,016 t_{x_{6}}+0,183 t_{x_{7}}+0,474 t_{x_{8}}
$$

де $t_{y}, t_{x_{1}}, \ldots, t_{x_{n}}$ - стандартизовані змінні, для яких середнє значення дорівнює нулю: $\overline{t_{y}}=\overline{t_{x_{i}}}=0$, а середнє квадратичне відхилення дорівнює одиниці: $\sigma_{t_{y}}=\sigma_{t_{x}}=1$.

Більш об'єктивну характеристику впливу параметру на якість підготовки інженера-педагога дали нам знайдені стандартизовані коефіцієнти регресії $\beta_{i}$ з рівняння (1), завдяки яким можна ранжувати параметри по "силі їх впливу" на результат. У нашому випадку: на 1 місці стоїть х8 (мотивація, $\beta_{8}=$ 
0,474); 2-му - $x_{1}$ (якість довузівської підготовки студента, $\beta_{1}=0,407$ ); на 3-му - $x_{2}$ (якість викладання в вузі, $\beta_{2}=0,237$ ); на 4-му $-x_{7}$ (культурно-освітній простір вузу, $\beta_{7}=0,183$ ); на 5-му $-x_{3}$ (тести академічних досягнень, $\beta_{3}=0,170$ ); на 6-му - $x_{5}$ (професійна спрямованість, $\beta_{5}=0,123$ ); на 7-му - $x_{6}$ (інтелект, креативність, $\beta_{6}=0,016$ ); на 8-му стоїть $x_{4}$ (педагогічне спілкування, $\beta_{4}=-0,619$ ). Дані аналізу побудови моделі представлено на рис. 1.

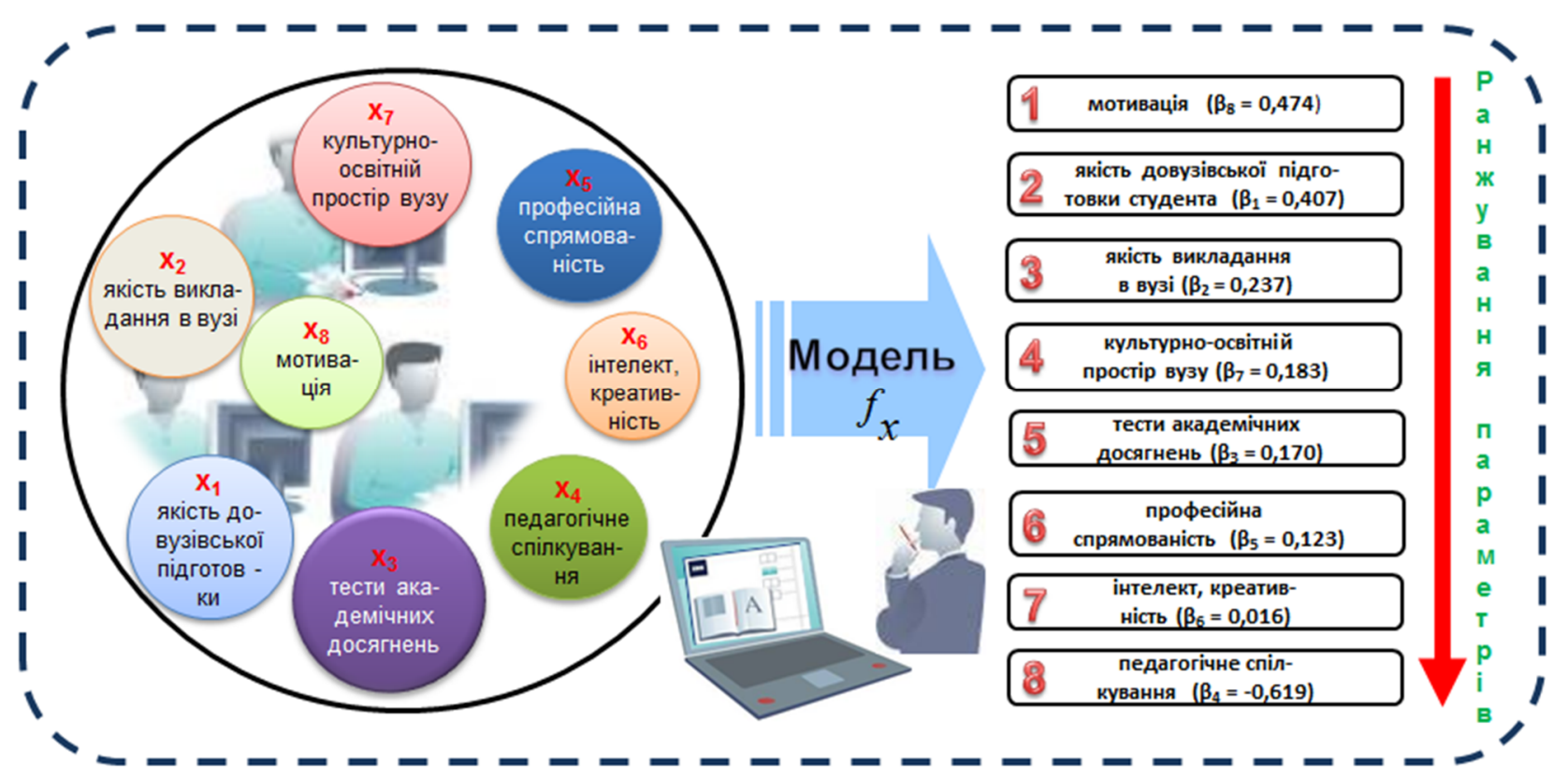

Рис. 1. Інтерпретація результатів констатуючого експерименту

3 рис. 1 можна бачити, що найбільший вплив на результативну ознаку має параметр мотивація $\mathrm{x}_{8}\left(\beta_{8}=0,474\right)$, щоб подивитися кількісну характеристику зміни цього параметра необхідно визначити його коефіцієнт еластичності. Так як значення параметра позитивне число, то згідно побудованої моделі збільшення даного параметра буде сприяти збільшенню величини якості підготовки інженера-педагога. Найменший вплив на підвищення якості має параметр інтелект, креативність - $\mathrm{x}_{6}\left(\beta_{6}=0,016\right)$. Аналіз результатів дослідження показали цікавий фракт, що збільшення параметру педагогічне спілкування $\mathrm{x}_{4}$ $\left(\beta_{4}=-0,619\right)$ призводить до зменшення якості підготовки студентів. Це перш за все пов'язано з тим, що збільшення обсягу і часу на вивчення професійно-орієнтованих педагогічних дисциплін сприятиме зниженню якості підготовки майбутнього інженера-педагога комп'ютерного профрілю. Деякі вчені вважають, що оптимізувати систему освіти в вузі можливо за рахунок скорочення необхідного обсягу матеріалу і залишення тільки тієї, яка вкрай необхідна молодому фахівцю. Але слід зауважити, що скорочення обсягу матеріалу, що вивчається не повинно призводити до скорочення обсягу інсрормації, необхідної інженеру-педагогу для подальшої професійної діяльності.

Продовжуючи вивчення проблеми якості професійної підготовки майбутніх інженерів-педагогів, слід визнати, що досі залишаються остаточно не розв'язані питання вибору оптимального співвідношення обсягу інженерного і педагогічного знань. Достатність такого обсягу, як зазначає В. Безрукова [3], поки що не підтверджена якимись чіткими критеріями і потребує кваліфікованого обґрунтування.

Для контролю якості підготовки майбутніх фахівців за даною технологією, описаній в роботі, необхідно контролювати зміну величин знайдених параметрів, що входять в модель. Практика показує, що досить це робити один раз на семестр за результатами сесії. Слід відмітити, що немає необхідності контролювати всі параметри, досить це робити вибірково, наприклад, контролювати параметр, який входить в модель зі знаком «мінус» (збільшення якого знижує якість підготовки) і параметри, які мають найбільший вплив на якість підготовки. Зауважимо, що дану модель можна використовувати в окремому ВН3 або групі вузів, але для цього потрібно скорегувати її за допомогою зібраного статистичного матеріалу даного вузу або групи вузів. 
Будуємо регресійну модель якості підготовки фрахівців в «чистому» вигляді:

$$
\begin{gathered}
y=0,632 \cdot x_{1}+0,258 \cdot x_{2}+0,314 \cdot x_{3}-0,966 \cdot x_{4}+0,162 \cdot x_{5} \\
+0,016 \cdot x_{6}+0,298 \cdot x_{7}+0,564 \cdot x_{8}-7,56
\end{gathered}
$$

де $y$ - значення якості професійної підготовки студентів, \%; $x_{1}, \ldots, x_{8}$ - оцінки параметрів моделі.

Однак виникає необхідність провести більш повне дослідження. Так як нам відома модель якості підготовки фахівців в чистому вигляді (див. формулу 2), то можна знайти приватні коефріцієнти еластичності. На відміну від парної регресії приватні рівняння регресії характеризують ізольований вплив чинника на результат, бо інші чинники закріплені на незмінному рівні. Завдяки отриманим значенням коефіцієнтів еластичності, які дорівнюють $Э \mathrm{x}_{1}=0,768, \ni \mathrm{x}_{2}=0,388, \ni \mathrm{x}_{3}=0,377, Э \mathrm{x}_{4}=-1,245$, $\ni x_{5}=0,244, \ni x_{6}=0,023, \ni x_{7}=0,386, Э x_{8}=0,853$ нам вдалося спрогнозувати залежність зміни якості підготовки студента від зміни ії параметрів на 1\%. Тобто при зміні першого параметру «якість довузівської підготовки студента» на 1\% якість професійної підготовки студентів приросте на 0,77\% і аналогічно з іншими коефріцієнтами еластичності, і відповідними їм параметрами якості.

Слід відмітити, той позитивний факт, що завдяки отриманим значенням коефіцієнтів еластичності можна робити безпосередньо прогноз динаміки розвитку якості підготовки студентів і здійснювати планування навчального процесу в вузі, спираючись на цей прогноз.

Сукупний вплив розглянутих параметрів на якість професійної підготовки майбутнього фрахівця визначається значенням індексу множинної кореляції, який оцінює тісноту спільного впливу параметрів на якість підготовки і обчислюється за формулою (3):

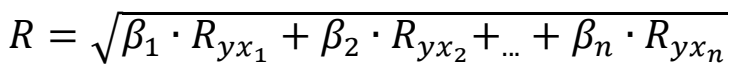

де $\beta_{1, \ldots .,} \beta_{n}$ - стандартизовані коефріцієнти регресії; $R_{y x_{1}}, \ldots, R_{y x_{n}}$ - парні коефіцієнти кореляції.

У нашому випадку коефіцієнт множинної кореляції дорівнює $\mathrm{R}=0,887$ і наближається до одиниці, що характеризує тісноту лінійного зв'язку між якістю підготовки $Y$ і нашими параметрами $x_{1}, x_{2}, \ldots, x_{8}$.

Далі ми визначили індекс множинної детермінації, що дорівнює в нашому випадку $R^{2}=0.887^{2}=$ 0.787. Коефріцієнт детермінації отриманої моделі має значення більше за 0,75. Відтак, можна говорити за достатню якість отриманої моделі, що дає змогу її використовувати в навчальному процесі інженерно-педагогічного вузу. Вплив інших, не врахованих в моделі параметрів, оцінюється як 1-R² 3 відповідною залишкової дисперсією $\mathrm{S}^{2}$.

Тобто, згідно зі статистичними даними 79\% на якість підготовки майбутніх інженерів-педагогів обумовлено впливом параметрів, які включені в модель, а на частку невідомих неврахованих параметрів, доводиться останні 21\%. Слід зауважити, що точність побудови моделі буде тим вище, чим більше статистичних даних використовувалося при побудові моделі, а також якщо включити ще додаткові параметри, кількість яких в моделі не обмежена.

Для оцінки статистичної значущості побудованого рівняння множинної регресії ми скористалися F-критерієм Фішера. Ми розрахували фактичне значення F-критерію Фішера за формулою (3.15) (спрощений варіант для перевірки нульової гіпотези $H_{0}: \beta_{1}=\beta_{2}=\cdots=\beta_{m}=0$ ):

$$
F=\frac{R^{2}}{1-R^{2}} \cdot \frac{n-m-1}{m}
$$

де $R^{2}$ - коефіцієнт (індекс) множинної детермінації, $m$ - число включених в модель параметрів, $n$ число спостережень, для нашого випадку, кількість експериментальних груп.

У нашому випадку $n=36, m=8$, тоді $F=12,47$. Порівняємо отримане значення 3 табличним. Табличне значення 3 рівнем надійності 0,05 при ступенях свободи $\mathrm{k}_{1}=8$ i k2 $=\mathrm{n}-\mathrm{m}-1=36-8-1=27$, $F_{k p}(8 ; 27)=2.3$. Оскільки фрактичне значення $F>F_{k p}$, то коефіцієнт детермінації статистично значимий $\mathrm{i}$ 
побудована математична модель якості підготовки майбутнього фахівця статистично надійна, отже, досліджувана залежність якості $Y$ досить добре описується включеними в модель параметрами: $x_{1}, x_{2}$, $\mathrm{x}_{3}, \mathrm{x}_{4}, \mathrm{x}_{5}, \mathrm{x}_{6}, \mathrm{x}_{7}, \mathrm{x}_{8}$. Таким чином, проведене дослідження і побудова математичної моделі якості підготовки майбутнього фахівця дозволило нам вирішити всі означені проблеми констатуючого експерименту.

Формувальний експеримент, що припав на діагностико-пошуковий, формувальноперетворювальний і частково на підсумково-узагальнювальний етапи дослідження, проводився впродовж 4-ох навчальних років для практичної перевірки моделі на адекватність. Вибірку складали дві групи студентів першого курсу контрольних (КГ) та експериментальних груп (ЕГ), які були залучені в констатувальному експерименті і навчалися у ВН3 з 1-го по 4-й курси відповідно.

Завдання формувального експерименту передбачали: формування на основі констатувального експерименту контрольних та експериментальних груп із студентів генеральної сукупності; впровадження в навчальний процес ВН3 математичної моделі якості професійної підготовки майбутніх фахівців інженерно-педагогічних спеціальностей; поетапне визначення рівнів якості професійної підготовки студентів на основі авторського комп'ютерного середовища «Diagnostic Center» та тестових технологій; впровадження результатів математичного моделювання авторського комп'ютерного середовища для удосконалення навчального процесу. У фрормувальному експерименті складали паралельні експериментальна (ЕГ) і контрольна (КГ) групи. Репрезентативність експерименту забезпечували майже однакова кількість студентів денної фрорми навчання: в КГ - 32 студента, а в ЕГ - 36 студента. Розроблена система заходів щодо виконання завдань формувального експерименту, що мала забезпечити формування у студентів високого рівня якості професійної підготовки, застосовувалася лише в експериментальної групі, відповідно до теоретично обґрунтованої нами математичної моделі якості професійної підготовки з дотриманням чітко визначених педагогічних умов. Навчання у контрольних групах здійснювалося за традиційними методикою навчання.

У дослідженні ми виходили з того, що перевірку гіпотези можна здійснити, якщо вивчати динаміку і рівні якості професійної підготовки майбутніх фахівців на різних етапах дослідження. Для цього нами проводилися контрольні зрізи на початку формувального експерименту, безпосередньо в процесі його проведення і після його завершення в контрольних і експериментальних групах.

Дослідно-експериментальна робота з перевірки ефективності побудованої математичної моделі якості професійної підготовки майбутнього інженера-педагога 3 дотриманням чітко визначених педагогічних умов здійснювалося нами на контрольному етапі дослідження. Вибірку складали ті самі студенти, які були залучені в констатувальному та формувальному експериментах. В обох категоріях груп була майже однакова кількість студентів, що повністю підтверджує вірогідність результатів нашого експериментального дослідження.

Обробка результатів експерименту на всіх етапах дослідження здійснювалася з використанням методів математичної статистики за допомогою авторського комп'ютерного середовища «Diagnostic Center». Оцінюючи рівень якості професійної підготовки майбутніх фрахівців, ми враховували виокремленні вісім параметрів, які визначались за допомогою оцінюючих шкал. Для кожного з них були відібрані та адаптовані діагностичні методики.

Ми дослідили динаміку результатів зміни рівнів якості параметрів контрольних (КГ) та експериментальних (ЕГ) груп студентів на етапах вхідного і підсумкового контролю. Порівняльні дані підсумкової діагностики рівнів показників якості підготовки майбутнього фахівця, що наведені та рис. 2, в КГ та ЕГ засвідчили про те, що і в КГ відбулися певні зрушення в підвищенні високого рівня параметрів якості, проте в порівнянні з даними, отриманими в ЕГ, вони виявилися незначними. Інтерпретація отриманих даних засвідчила, що найбільш значущі позитивні зміни в ЕГ спостерігалися за такими параметрами, як рівень якості довузівської підготовки студента (кількість студентів з високим рівнем збільшилася на 9,07\%), рівень якості викладання в вузі (з високим рівнем кількість студентів зросла на 8,07\%), тести академічних досягнень (високий рівень збільшився на 9,7\%), мотивація (високий рівень збільшився на 8,38 \%).

Зауважимо, що зміни показників високого рівня наступних параметрів були менш значними: рівень педагогічного спілкування збільшився на 0,37\%; рівень профресійної спрямованості збільшився на 
1,28\%; кількість студентів із високим рівнем інтелекту, креативності збільшилася на 0,52\%; рівень культурно-освітній простір вузу також збільшився на 1,36\%.

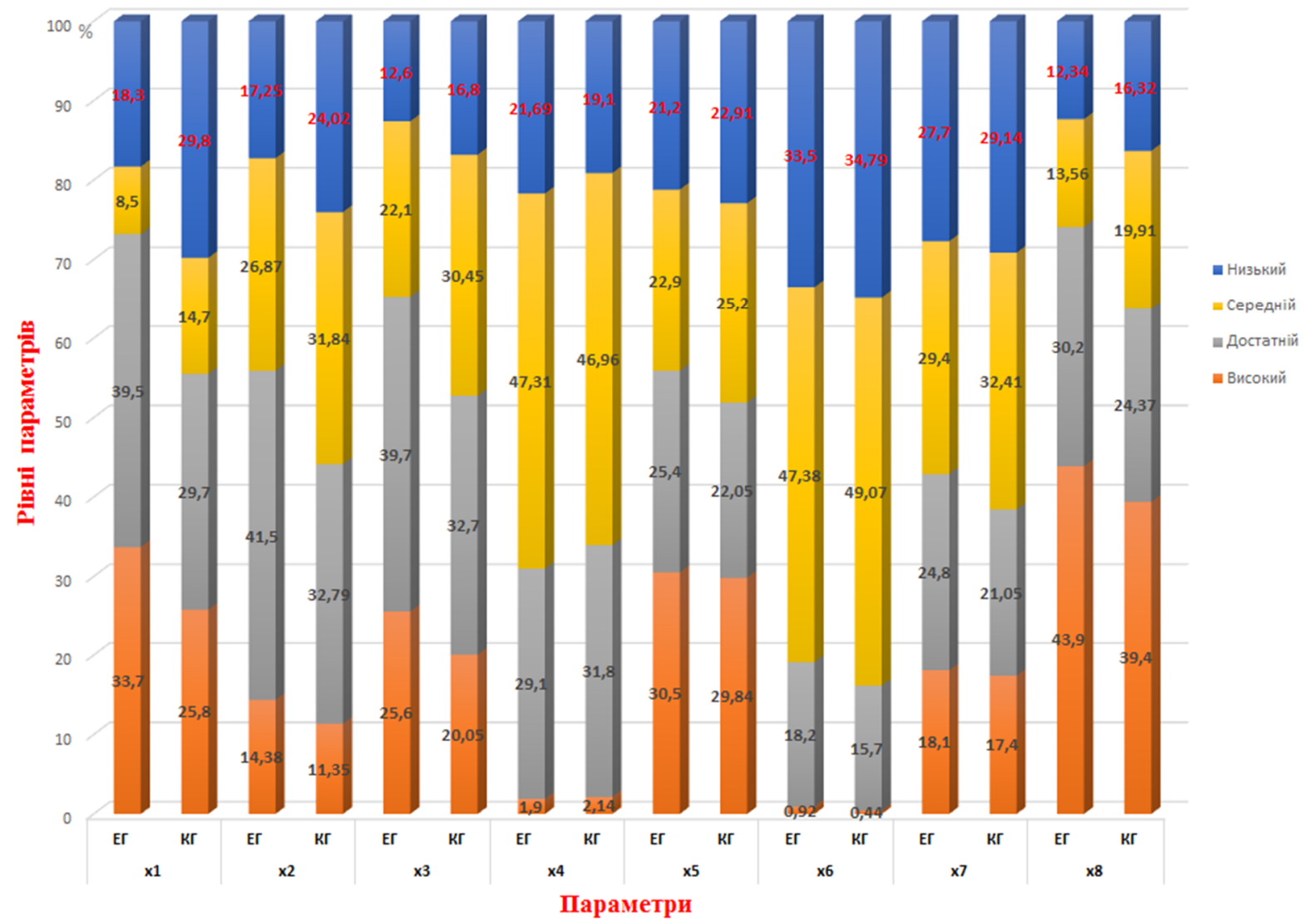

Рис. 2. Діаграма динаміки результатів зміни рівнів якості параметрів контрольних (КГ) та експериментальних (ЕГ) груп студентів на підсумковому контролі

Далі в табл. 1 і на рис. 3 ми навели результати контрольного експерименту для студентів ЕГ, що показують динаміку рівнів параметрів якості по відношенню до вагових балів параметрів якості математичної моделі.

Табл. 1. Динаміка рівнів параметрів якості в порівнянні з ваговими балами параметрів математичної моделі (результати контрольного експерименту в ЕГ)

\begin{tabular}{|c|c|c|c|c|c|c|c|c|c|c|}
\hline \multirow{3}{*}{ 혼 } & \multirow{3}{*}{$\begin{array}{l}\text { Рівні якості } \\
\text { параметрів }\end{array} \mid$} & \multirow{3}{*}{ 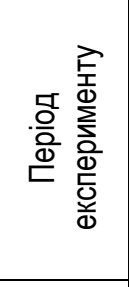 } & \multicolumn{8}{|c|}{ Параметри } \\
\hline & & & $\begin{array}{c}\mathrm{x}_{1-} \\
\text { якість } \\
\text { довузівської } \\
\text { підготовки }\end{array}$ & \begin{tabular}{|c|} 
Х2- \\
якість \\
викладання \\
в вузі \\
\end{tabular} & $\begin{array}{c}\mathrm{x}_{3}- \\
\text { тести } \\
\text { академічних } \\
\text { досягнень }\end{array}$ & $\begin{array}{c}\mathrm{x}_{4}- \\
\text { педагогічне } \\
\text { спілкування }\end{array}$ & $\begin{array}{c}x_{5}- \\
\text { профресійна } \\
\text { спрямованість }\end{array}$ & $\begin{array}{c}\text { Х6- } \\
\text { інтелект, } \\
\text { креативність }\end{array}$ & \begin{tabular}{|c|} 
Х7- \\
культурно- \\
освітній \\
простір \\
вузу \\
\end{tabular} & $\begin{array}{c}\text { Х8- } \\
\text { мотивація }\end{array}$ \\
\hline & & & $\%$ & $\%$ & $\%$ & $\%$ & $\%$ & $\%$ & $\%$ & $\%$ \\
\hline \multirow[b]{3}{*}{$\mathrm{E} \Gamma$} & \multirow{2}{*}{\begin{tabular}{|c|} 
Високий \\
рівень \\
якості \\
параметрів \\
\end{tabular}} & Початок & 24,63 & 6,31 & 15,9 & 1,53 & 29,22 & 0,4 & 16,74 & 35,52 \\
\hline & & Кінець & 33,7 & 14,4 & 25,6 & 1,9 & 30,5 & 0,92 & 18,1 & 43,9 \\
\hline & \multicolumn{2}{|c|}{$\begin{array}{c}\text { Вагові бали якості } \\
\text { підготовки } \beta_{i} \text { згідно } 3 \\
\text { побудованою } \\
\text { математичною } \\
\text { моделлю } \\
\end{array}$} & 40,7 & 23,7 & 17 & $-61,9$ & 12,3 & 1,6 & 18,3 & 47,4 \\
\hline
\end{tabular}




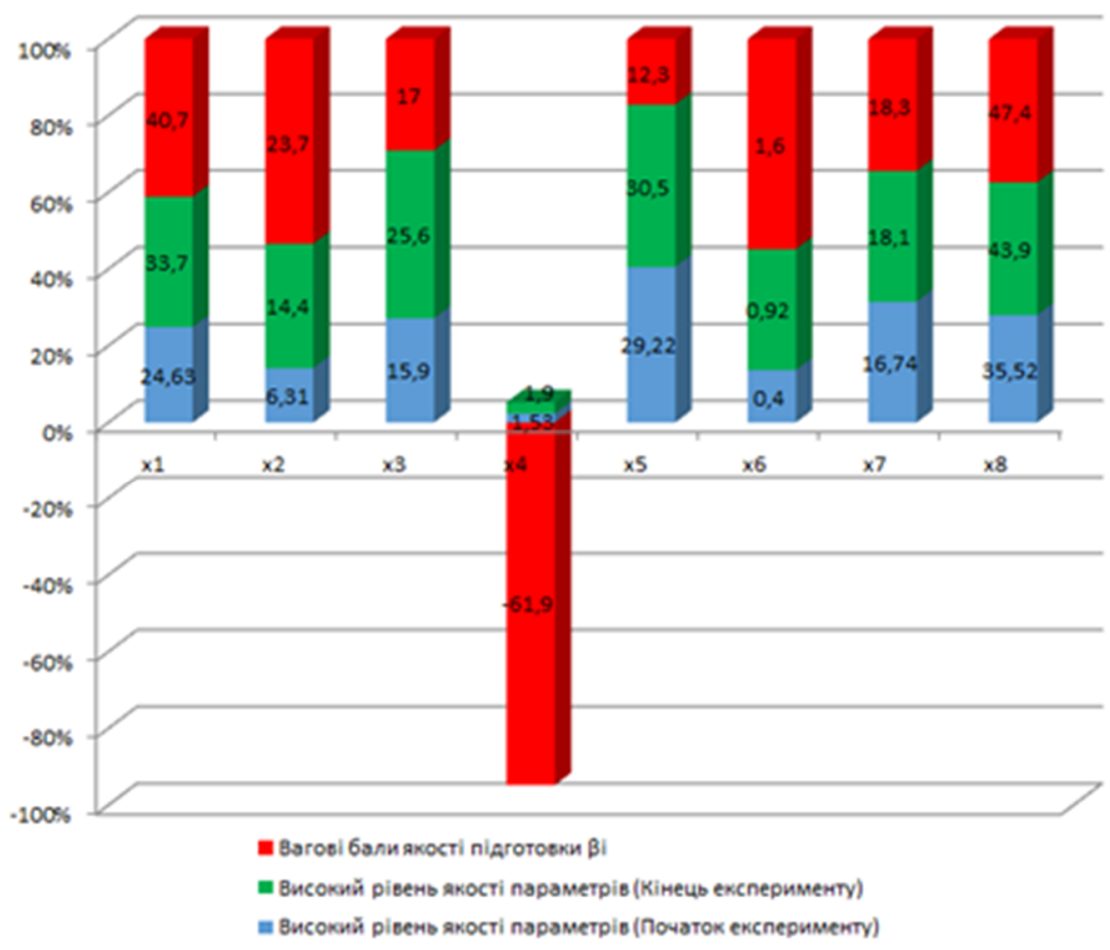

Рис. 3. Діаграма динаміки рівнів параметрів, що впливають на якість підготовки фрахівців (результати контрольного експерименту в ЕГ)

Порівняння результатів вхідного і підсумкового контролю на рис. 3. показало наявність статистичної значущості позитивної зміни рівнів параметрів якості в експериментальній групі. Дана обставина свідчить про ефрективність розробленої математичної моделі якості підготовки фахівця. Як ми бачимо з рис. 3, графічне подання вагових балів параметрів математичної моделі дозволяє наочно продемонструвати, які показники якості і до якої межі необхідно покращувати в процесі підготовки майбутнього фахівця.

За даними табл. 1 та згідно з побудованим рівнянням регресії в «чистому» вигляді (див. формулу 2) ми визначили теоретичне значення якості підготовки студентів ЕГ на етапі підсумкового контролю.

$$
\begin{gathered}
y=0,632 \cdot 33,7+0,258 \cdot 14,4+0,314 \cdot 25,6-0,966 \cdot 1,9+0,162 \cdot 30,5+ \\
+0,016 \cdot 0,92+0,298 \cdot 18,1+0,564 \cdot 43,9-7,56=54 \% .
\end{gathered}
$$

Слід зазначити, що теоретичне значення якості підготовки дорівнює $54 \%$, а її значення знайдене експериментальним шляхом відрізняється незначно від теоретичного на 4,32 \% і дорівнює 49,7 \%, що підтверджує адекватність побудованої математичної моделі.

Отже, отримані під час експериментальної роботи дані засвідчили статистичні зміни якості навчального процесу та рівнів параметрів якості підготовки фахівця. Це дозволило зробити висновок про ефективність та дієвість упровадження у навчальний процес вищих навчальних закладів запропонованої нами інноваційної методики комплексного діагностування рівнів параметрів якості та математичної моделі, а також доцільність визначених педагогічних умов з корекції рівнів параметрів якості.

У процесі експериментального дослідження відпрацьовано організаційно-методичні рекомендації до впровадження математичної моделі якості підготовки студентів за допомогою комп'ютерного середовища «Diagnostic Center» як умови ефективного управління навчальним процесом. 


\section{IV Обговорення}

Існуючі підходи до моделювання в основному даються на описовому (теоретичному) рівні і не мають практично-прикладного характеру, що в свою чергу визначається рядом недоліків: вони не створюють основу для подальшого професійного та особистісного розвитку студента; не дають чіткого відповідь на питання, які критерії і параметри впливають на якість підготовки майбутнього фрахівця; якими ефективними інструментами потрібно вимірювати рівень підготовленості студентів для того, щоб в подальшому вибирати правильні шляхи вдосконалення якості, відстежувати його динаміку, а також приймати правильні та науково обірунтовані рішення. Для усунення названих та багатьох інших недоліків, що існують сьогодні, ми пропонуємо в навчально-виховний процес вузу впроваджувати наукові підході до вимірювання якості підготовки майбутнього фрахівця та інноваційні методи діагностування з використанням засобів інформаційних технологій, а саме застосування авторського комп'ютерного середовища «Diagnostic Center».

Перевірка ефективності отриманих результатів дослідження визначалася на основі порівняння рівнів показників якості експериментальної і контрольної груп на початку, в ході, і в кінці експериментального дослідження. Для цього використовувалися опитування, анкетування, комп'ютерне діагностування, аналіз результатів діяльності студентів, методи математичної статистики і комп'ютерної обробки даних, шкалування та інші методики.

Порівняльні дані підсумкової діагностики рівнів показників якості підготовки майбутнього фрахівця в контрольній та експериментальній групах після проведення формуючого експерименту засвідчили про те, що і в контрольній групі відбулися певні зрушення в підвищенні високого рівня параметрів якості, проте в порівнянні з даними, отриманими в експериментальній групі, вони виявилися незначними. Інтерпретація отриманих даних також засвідчила, що найбільш значущі позитивні зміни в ЕГ спостерігалися за такими параметрами, як рівень якості довузівської підготовки студента (кількість студентів з високим рівнем збільшилася на 9,07\%), рівень якості викладання в вузі (з високим рівнем кількість студентів зросла на 8,07\%), тести академічних досягнень (високий рівень збільшився на 9,7\%), мотивація (високий рівень збільшився на 8,38 \%). Зауважимо, що зміни показників високого рівня наступних параметрів були менш значними: рівень педагогічного спілкування збільшився на 0,37\%; рівень професійної спрямованості збільшився на 1,28\%; кількість студентів із високим рівнем інтелекту, креативності збільшилася на 0,52\%; рівень культурно-освітній простір вузу також збільшився на 1,36\%.

Експериментальне дослідження підтвердило, що реалізація розробленої нами математичної моделі, комп'ютерного середовища «Diagnostic Center» для діагностування та виявлених педагогічних умов забезпечує підвищення якості підготовки майбутнього інженера-педагога та дає можливість науково коригувати навчальний процес вузу.

\section{V Висновки}

Таким чином, під час проведення дослідно-експериментальної роботи було перевірено ефективність розробленої методики комплексного діагностування рівнів параметрів якості за допомогою авторського комп'ютерного середовища «Diagnostic Center» та математичної моделі.

За допомогою множинного кореляційного аналізу була побудована математична модель, що включає в себе вісім науково-обґрунтованих параметрів, які впливають на якість підготовки майбутнього інженера-педагога з певними коефріцієнтами. Хотілось би акцентувати увагу на незаперечної важливості застосування математичних методів, а особливо в педагогічній діагностиці, оскільки вони не тільки дають можливість аналізу і оцінки навчальних досягнень студентів, а й дозволяють розкрити неявні проблеми, вирішення яких, може виявитися куди більш важливим, ніж досягнення попередніх цілей. У нашому випадку, застосування методу множинного кореляційного аналізу дозволило дати відповіді на питання, що нас цікавили, а саме: «ЯК забезпечується досягнення заданих цілей?», «ЯК здійснюється траєкторія особистісно-професійного становлення майбутнього фрахівця?», «ЯКІ перспективи розвитку якості підготовки майбутніх випускників?» і тощо. Крім того, нами була вирішена ще одна задача - була показана нерівнозначність параметрів і зроблена спроба оцінки ваги впливу кожного з них на якість підготовки майбутнього фахівця. 
Запропонована модель $є$ універсальною, що дозволяє ї̈ трансформувати й реалізовувати 3 урахуванням специфіки різних ВН3, напрямів підготовки майбутніх фахівців, впливу зовнішніх і внутрішніх чинників. Ї̈ особливістю $€$ те, що вона має практично-прикладний характер, яка дає чітку відповідь на питання, як здійснювати професійну підготовку майбутніх фахівців і вдосконалювати якість навчального процесу.

Аналіз результатів КГ та ЕГ засвідчив наявність розбіжності у зміні діагностованих параметрів якості. Для з'ясування та корекції параметрів якості майбутніх інженерів-педагогів були розроблені діагностичні тести, які оцінювалися чотирьохрівневою шкалою (низький, середній, достатній і високий рівні) для всіх розглянутих в дослідженні параметрів і якості в цілому.

Достовірність результатів зафіксованих під час проведення педагогічного експерименту підтверджена за допомогою F-критерію Фішера. Отже, доведено, що результати експериментальної перевірки підтверджують ефективність запропонованої методики комплексного діагностування рівнів параметрів якості підготовки майбутніх інженерів-педагогів комп'ютерного профрілю.

Оскільки в роботі використовуються ймовірнісно-статистичні методи для вивчення процесу профеесійної підготовки майбутнього інженера-педагога завжди існує можливість коригування та вдосконалення розглянутої в роботі математичної моделі якості підготовки майбутнього фахівця 3 урахуванням конкретних умов (наприклад, науково-матеріальної бази вузу, професорськовикладацького складу, технології освіти і виховної роботи, організації вузівської науки, шкали оцінювання, методів збору статистичного матеріалу та інші).

Проведене дослідження не вичерпує всіх аспектів проблеми управління якістю навчального процесу у вищому навчальному закладі. До перспективних напрямів подальших наукових розвідок відносимо такі:

- на сучасному етапі розвитку суспільства часто виникає необхідність перекваліфікації фрахівця за короткий проміжок часу, тому актуальною є задача, яка пов'язана з питаннями прогнозування можливість будувати перспективну стратегію розвитку якості підготовки фахівця в майбутньому;

- подальшого дослідження потребують питання розробки й обгрунтування оптимального співвідношення між дисциплінами спеціального та педагогічного циклу в змісті профресійної підготовки майбутнього інженера-педагога.

\section{Бібліографрічні посилання}

1. Анан'єва Н. В., Литвинова Н. В. Особливості інженерно-педагогічної освіти в умовах реформування освітньої системи в Україні. Вісник Глухівського національного педагогічного університету імені Олександра Довженка. Сер. : Педагогічні науки. 2012. Вип. 21. С. 160-165.

2. Байдацька Н. М. Педагогічні умови моніторингу якості навчальних досягнень студентів у вищих навчальних закладах недержавної форми власності : дис. ... канд. пед. наук : 13.00.04. Вінниця, 2007. 220 с.

3. Безрукова В. С. Педагогика. Проективная педагогика : Учеб. пособие для инженерно-педагогических институтов и индустриально-педагогических техникумов. Екатеринбург : Деловая книга, 1996. 344 с.

4. Єфремова О. В. Діагностування рівнів якості професійної підготовки майбутніх інженерів-педагогів. Теоретичні та практичні аспекти розвитку сучасної педагогіки та психології : збірник тез наукових робіт учасників міжнародної науковопрактичної конференції (м. Львів, 26-27 червня 2020 року). Львів: ГО «Львівська педагогічна спільнота», 2020. С. 133136.

5. Єфремова О. В. Побудова математичної моделі якості професійної підготовки фахівців інженерно-педагогічного профілю. Нові технології навчання: наук. - метод. зб. Інститут інноваційних технологій і змісту освіти МОНмолодьспорт України. Київ., 2011. Вип. 68. С. 111-115.

6. Завистовский С. Э. Моделирование компетентности современного выпускника вуза : инновационные подходы. Непрерывная подготовка педагогов технологического образования и профессионального обучения: интеграция, теория и практика. Материалы XI междунар. науч.-практ. конф. Ульяновск, 2016. С. 126-129.

7. Згуровський М.3. Болонський процес - структурна ресрорма вищої освіти на європейському просторі. Біржова торгівля.4004. 2007. Вип. 18. 52 c. URL: http://kpi.ua/bologna. (дата звернення: 05.01.2018).

8. Канивец П. И. Модели и методы оценки качества подготовки и повышения конкурентоспособности специалистов: дис. ... канд. эконом. наук : 08.00.13. Новочеркасск, 2004. 231 с.

9. Кінаш І. П. Якість освіти як результат, процес та освітня система. Науковий вісник НЛТУ України. 2011. Вип. 21.5. С. 363368.

10. Коваленко О. Е. Інженерно-педагогічні кадри: нові вимоги сьогодення. Проблеми інженерно-педагогічної освіти: зб. наук. пр. Укр. інж.- пед. акад. Харків, 2012. Вип. 21. С. 8-17. 
11. КоробовичЛ.П. Педагогічні умови моніторингу результативності навчального процесу в системі педагогічного менеджменту приватного вищого навчального закладу : автореф. дис. ... канд. пед. наук : 13.00.06. Київ, 2011. 20 с.

12. Международный стандарт ISO 9001:2015. Системы менеджмента качества. Tребования. URL: https://pqmonline.com/assets/files/pubs/translations/std/iso-9001-2015-(rus).pdf. (дата звернення: 09.07.2020).

13. Мережко Н. В., Осієвська В. В., Ясинська Н. С. Управління якістю. Київ: КНТЕУ, 2010. 216 с.

14. Наконечний С. І., Терещенко Т. О., Романюк Т. П. Економетрія: навч. посіб. Київ: КНЕУ, 2004. 352 с.

15. Олеандр Т. М. Моніторинг якості природничо-наукової освіти в університетах США : автореф. дис. ... канд. пед. наук : 13.00.01. Тернопіль, 2011. 22 с.

16. Олендр Т. М. Єдина моніторингова система управління освітою як ефективний механізм підвищення якості освітніх послуг. Освіта та наука на хіміко-біол. факульт. ТНПУ ім. В. Гнатюка (1940-2010): матер. регіон. наук. - практ. конф. Тернопіль, 2010. С. 73-75.

17. Потай И. Ю. Оценка качества подготовки специалистов в вузе. Український журнал «Економіст». 2014. №5 (331). С. 2327.

18. Потай И. Ю. Разработка функциональной модели Системы управления качеством подготовки специалистов в ВУЗе : зб. наук. праць НУК. Миколаїв: НУК, 2006. №5 (410). С. 72-82.

19. Рогожин В. М., Елагина В. С. Современная модель подготовки специалистов. Современные проблемы науки и образования. 2017. № 6. URL: http://www.science-education.ru/ru/article/view?id=27136 (дата обращения: 09.07.2020)

20. Сергеева Е. В. Мониторинг учебных достижений студентов в системе управления качеством подготовки специалистов в педагогическом вузе : автореф. дис. ... канд. пед. наук : 13.00.08. Волгоград, 2011. 27 с.

21. Стандарти і рекомендації щодо забезпечення якості в Європейському просторі вищої освіти. Київ : Ленвіт, 2006. 35 с.

22. Суслов А. Г., Авдиенко А. Г. Система оценки качества подготовки специалиста. Качество. Инновации. Образование. 2005. № 3. C. 58-61.

23. Туржанська О. С. Організаційно-педагогічні умови моніторингу якості підготовки майбутніх учителів математики : автореф. дис. ... канд. пед. наук : 13.00.04. Вінниця, 2012. 20 с.

24. Шабанов Г. А. Педагогическое обеспечение качества образования в вузе : дис. ... д-ра пед. наук: 13.00.08. Москва, 2006. 407 c.

25. Щербак О. І. Професійно-педагогічна освіта: теорія і практика: монографія / за ред. Н.Г. Ничкало. Київ: Наук. Світ, 2010. $314 \mathrm{c}$.

26. Becket N., Brookes M. Analysing Quality Audits in Higher Education. Brookes eJournal of Learning and Teaching, January 2005. Vol. 1. P. 2. - 13.

27. Brookes M., Downie N. Managing Change: The Value of Student Feedback. EuroCHRIE Congress Barcelona, 2002. P. 132138.

28. Centre for Higher Education Policy Studies. URL: http://www. utwente.nl/bms/cheps. (дата звернення 05.07.2020)

29. Kuzmenko O. Corporate University: Ukrainian and world practice. The Advanced Science Journal. 2014. No 4. P. 46-49. doi: 10.15550/ASJ.2014.09.046

30. Powell A., Hunt A., Irving A. Evaluation of Courses by Whole Student Cohorts: a case study. Assessment and Evaluation in Higher Education. 1997. 22 (4). P. 397 - 404.

31. Ramsden P. A. Performance Indicator of Teaching Quality in Higher Education: the Course Expereince Questionnaire. Studies in Higher Education. 1991. 16 (2). P. 129 - 150.

32. Tam M. University Impact on Student Growth: a Quality Measure? Journal of Higher Education Policy and Management. 2002. 24 (2). P. 211-218.

33. Weert E. Higher education in the Netherlands. Country report. Twente: CHEPS, 2007. 75 p.

\section{References}

1. Ananieva, N. V., Litvinova, N. V. (2012). Features of engineering and pedagogical education in the conditions of reforming the educational system in Ukraine [Osoblyvosti inzhenerno-pedahohichnoi osvity v umovakh reformuvannia osvitn'oi systemy v Ukraini]. Bulletin of Hlukhiv National Pedagogical University named after Oleksandr Dovzhenko. Ser. : Pedagogical sciences [Visnyk Hlukhivskoho natsionalnoho pedahohichnoho universytetu imeni Oleksandra Dovzhenka. Ser. : Pedahohichni nauky], 21, 160-165. [in Ukrainian]

2. Baidatska, N. M. (2007). Pedagogical conditions for monitoring the quality of students' academic achievements in higher educational institutions of non-state ownership [Pedaghoghichni umovy monitorynghu jakosti navchaljnykh dosjaghnenj studentiv u vyshhykh navchaljnykh zakladakh nederzhavnoji formy vlasnosti]. Pedagogic science candidate author's abstract, 13.00.04, Vinnycja, 220. [in Ukrainian]

3. Bezrukova, V. S. (1996). Pedagogy. Projective pedagogy [Pedagogika. Proektivnaya pedagogika]. Textbook for engineering and pedagogical institutes and industrial pedagogical colleges. [Ucheb. posobie dlya inzhenerno-pedagogicheskih institutov $\mathrm{i}$ industrial'no-pedagogicheskih tekhnikumov], Yekaterinburg: Business Book, 344. [in Russian]

4. Yefremova, O. V. (2011). Construction of a mathematical model of the quality of professional training of engineering and pedagogical specialists [Pobudova matematychnoi modeli yakosti profesiinoi pidhotovky fakhivtsiv inzhenerno-pedahohichnoho profiliu]. New learning technologies: science. - method. zb. Institute of Innovative Technologies and Content of Education, Ministry of Education and Science of Ukraine [Novi tekhnolohii navchannia: nauk. - metod. zb. Instytut innovatsiinykh tekhnolohii i zmistu osvity MONmolodsport Ukrainy], Kiev, 68, 111-115. [in Ukrainian] 
5. Yefremova, O. V. (2020). Diagnosing the quality levels of professional training of future engineers-teachers [Diahnostuvannia rivniv yakosti profesiinoi pidhotovky maibutnikh inzheneriv-pedahohiv]. Theoretical and practical aspects of the development of modern pedagogy and psychology: a collection of abstracts of scientific papers of the participants of the international scientificpractical conference [Teoretychni ta praktychni aspekty rozvytku suchasnoi pedahohiky ta psykholohii : zbirnyk tez naukovykh robit uchasnykiv mizhnarodnoi naukovo-praktychnoi konferentsii]. (Lviv, June 26-27, 2020). Lviv: NGO "Lviv Pedagogical Community", 133-136. [in Ukrainian]

6. Zavistovskij, S. E. (2016). Modeling the competence of a modern university graduate: innovative approaches [Modelirovanie kompetentnosti sovremennogo vypusknika vuza : innovacionnye podhody]. Continuous training of teachers of technological education and vocational training: integration, theory and practice. Materials XI int. scientific-practical conf [Nepreryvnaya podgotovka pedagogov tekhnologicheskogo obrazovaniya i professional'nogo obucheniya: integraciya, teoriya i praktika. Materialy HI mezhdunar. nauch.-prakt. konf. Ul'yanovsk], Ulyanovsk, 126-129. [in Russian]

7. Zghurovskyi, M. Z. (2007). The Bologna Process is a structural reform of higher education in Europe [Bolonskyi protses strukturna reforma vyschoi osvity na yevropeiskomu prostori]. Exchange trade.-4004, 18, 52. URL: http://kpi.ua/bologna (data zvernennya: 05.01.2018). [in Ukrainian]

8. Kanivec, P. I. (2004). Models and methods for assessing the quality of training and improving the competitiveness of specialists [Modeli i metody ocenki kachestva podgotovki i povysheniya konkurentosposobnosti specialistov]. Dissertation of the candidate of economic sciences, 08.00.13. Novocherkassk, 223. [in Russian]

9. Kinash, I. P. (2011). Quality of education as a result, process and educational system [Yakist osvity yak rezultat, protses ta osvitnia systema]. Scientific Bulletin of NLTU of Ukraine [Naukovyi visnyk NLTU Ukrainy], 21.5, 363-368. [in Ukrainian]

10. Kovalenko, O. E. (2012). Engineering and pedagogical staff: new requirements of today [Inzhenerno-pedahohichni kadry: novi vymohy s'ohodennia]. Problems of engineering and pedagogical education: a collection of sciences. prot Ukr. eng.- ped. Acad [Problemy inzhenerno-pedahohichnoi osvity: zb. nauk. pr. Ukr. inzh.- ped. akad], Kharkiv, 21, 8-17. [in Ukrainian]

11. Korobovych, L. P. (2011). Pedagogical conditions for monitoring the effectiveness of the educational process in the system of pedagogical management of a private higher education institution [Pedahohichni umovy monitorynhu rezultatyvnosti navchalnoho protsesu v systemi pedahohichnoho menedzhmentu pryvatnoho vyschoho navchalnoho zakladu]. Pedagogic science candidate author's abstract, 13.00.06, Kiev, 20. [in Ukrainian]

12. International standard ISO 9001: 2015. Quality Management Systems. Requirements. URL: https://pqmonline.com/assets/files/pubs/translations/std/iso-9001-2015-(rus).pdf. (accessed: 09.07.2020).

13. Merezhko, N. V., Osiievska, V. V., Yasynska, N. S. (2010). Quality management [Upravlinnia yakistiu]. Kyiv: KNTEU, 216. [in Ukrainian]

14. Nakonechnyi, S. I., Tereschenko, T. O., Romaniuk, T. P. (2004). Econometrics: a textbook [Ekonometriia: navch. posib]. Kyiv: KNEU, 352. [in Ukrainian]

15. Oleandr, T. M. (2011). Monitoring the quality of science education in the United States [Monitorynh yakosti pryrodnychonaukovoi osvity v universytetakh SShA]. Pedagogic science candidate author's abstract, 13.00.01. Ternopil, 22. [in Ukrainian]

16. Olendr, T. M. (2010). The only monitoring system of education management as an effective mechanism for improving the quality of educational services [Yedyna monitorynhova systema upravlinnia osvitoiu yak efektyvnyi mekhanizm pidvyschennia yakosti osvitnikh posluh]. Education and science in chemical and biol. faculty. TNPU them. V. Hnatyuk (1940-2010): mater. region. science. - practical. conf [Osvita ta nauka na khimiko-biol. fakult. TNPU im. V. Hnatiuka (1940-2010): mater. rehion. nauk. - prakt. Konf]. Ternopil, 73-75. [in Ukrainian]

17. Potaj, I. Yu. (2014). Evaluation of the quality of training in the university [Ocenka kachestva podgotovki specialistov v vuze]. Ukrainian magazine "Economist" [Ukrainskyi zhurnal «Ekonomist»], 5 (331), 23-27. [in Ukrainian]

18. Potai, Y. Yu. (2006). Development of a functional model of a quality management system for training specialists at a university [Razrabotka funktsyonalnoi modely Systemb upravlenyia kachestvom podhotovky spetsyalystov v VUZe]. Collection of scientific works of NUK [Zb. nauk. prats NUK]. Mykolaiv: NUK, 5 (410), 72-82. [in Ukrainian]

19. Rogozhin, V. M., Elagina, V. S. (2017) The modern model of specialist training [Sovremennaya model' podgotovki specialistov]. Modern problems of science and education [Sovremennye problemy nauki i obrazovaniya], 6. URL: http://www.scienceeducation.ru/ru/article/view?id=27136 (accessed: 09.07.2020). [in Russian]

20. Sergeeva, E. V. (2011). Monitoring student academic achievement in the quality management system of specialist training at a pedagogical university [Monitoring uchebnyh dostizhenij studentov v sisteme upravleniya kachestvom podgotovki specialistov v pedagogicheskom vuze]. Pedagogic science candidate author's abstract, 13.00.08, Volgograd, 27. [in Russian]

21. Standards and recommendations for quality assurance in the European Higher Education Area. Kyiv: Lenvit, 2006, 35. [in Ukrainian]

22. Suslov, A. H., Avdyenko, A. H. (2005). A system for assessing the quality of specialist training [Systema otsenky kachestva podhotovky spetsyalysta]. Quality. Innovation Education [Kachestvo. Ynnovatsyy. Obrazovanye], 3, 58-61. [in Russian]

23. Turzhanska, O. S. (2012). Organizational and pedagogical conditions for monitoring the quality of training of future mathematics teachers [Orhanizatsiino-pedahohichni umovy monitorynhu yakosti pidhotovky maibutnikh uchyteliv matematyky]. Pedagogic science candidate author's abstract, 13.00.04, Vinnytsia, 20. [in Ukrainian]

24. Shabanov, G. A. (2006). Pedagogical support of the quality of education at the university [Pedagogicheskoe obespechenie kachestva obrazovaniya v vuze]. Dissertation of a doctor of pedagogical sciences, 13.00.08. Moscow, 407. [in Russian]

25. Scherbak, O. I. (2010). Professional and pedagogical education: theory and practice: monograph [Profesiino-pedahohichna osvita: teoriia i praktyka: monohrafiia] / N.H. Nychkalo. Kyiv: Nauk. Svit, 314. [in Ukrainian] 
26. Becket, N., Brookes, M. (2005) Analysing Quality Audits in Higher Education. Brookes eJournal of Learning and Teaching, Vol1, 2-13.

27. Brookes, M., Downie. N. (2002). Managing Change: The Value of Student Feedback. EuroCHRIE Congress Barcelona, 132 138.

28. Centre for Higher Education Policy Studies. URL: http://www. utwente.n//bms/cheps. (accessed 05.07.2020)

29. Kuzmenko, O. (2014). Corporate University: Ukrainian and world practice. The Advanced Science Journal, 4, 46-49. doi: 10.15550/ASJ.2014.09.046

30. Powell, A., Hunt, A., Irving, A. (1997). Evaluation of Courses by Whole Student Cohorts: a case study. Assessment and Evaluation in Higher Education, 22 (4), 397 - 404.

31. Ramsden, P. A. (1991). Performance Indicator of Teaching Quality in Higher Education: the Course Expereince Questionnaire. Studies in Higher Education, 16 (2), 129 - 150.

32. Tam, M. (2002). University Impact on Student Growth: a Quality Measure? Journal of Higher Education Policy and Management, 24 (2), $211-218$.

33. Weert, E. (2007). Higher education in the Netherlands. Country report. Twente: CHEPS, 75.

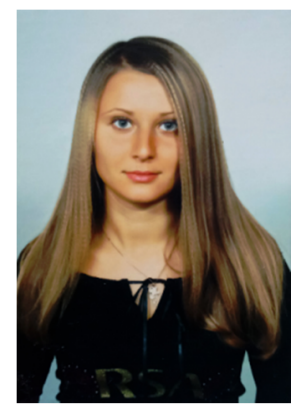

\section{Єфремова Оксана Володимирівна,}

аспірантка,

Інститут педагогічної освіти і освіти дорослих НАПН України,

вул. М. Берлинського, 9, м. Київ, Україна, 04060.

Тел. +38(050)982-38-27. E-mail: efremovaoksana7@gmail.com

\section{Yefremova Oksana Volodymyrivna,}

graduate student,

Institute of Pedagogical and Adult Education NAPS of Ukraine,

st. M. Berlinsky, 9, Kyiv, Ukraine, 04060.

Tel. +38(050)982-38-27. E-mail: efremovaoksana7@gmail.com

ORCID: 0000-0002-0280-8084

\section{Citation (APA):}

Yefremova, O. (2020). Improving the efficiency of assessing the quality of training of future engineers-teachers using the author's mathematical model. Engineering and Educational Technologies, 8 (3), 8-23. doi: https://doi.org/10.30929/2307-9770.2020.08.03.01

\section{Цитування (ДСТУ 8302:2015):}

Єфремова О. В. Підвищення ефрективності оцінювання якості підготовки майбутніх інженерів-педагогів за допомогою авторської математичної моделі / Інженерні та освітні технології. 2020. Т. 8. № 3. С. 8-23. doi: https://doi.org/10.30929/23079770.2020 .08 .03 .01

Обсяе статmі: сторінок - 16 ; умовних друк. аркушів - 2,318. 